\section{Research grants or handouts?}

\section{Paris}

WHEN is a government research subsidy really just an old-fashioned bail-out? Just ask Sir Leon Brittan. The zealous competition commissioner of the European Communities (EC) is on a crusade to level the playing fields of the European marketplace, stamping out unfair government aid to industry wherever he finds it. And woe to the company that falls within his sights, for he has the power to call a research grant a hand-out in disguise - and stop it in its tracks.

Under the Treaty of Rome, the EC's rule book, "any aid granted by a member state in any form which distorts or threatens to distort competition by favouring certain undertakings" is forbidden. Depending on the nature of the funding, that stricture can prohibit research and development subsidies for state-owned companies. And this is something that French officials in particular are finding increasingly restrictive.

This spring, for instance, Brittan halted a French government plan to invest FF 2,650 million ( $\$ 450$ million) into research and development at Groupe Bull, the French state-owned computer and electronics company. Brittan suspected that the money was really an illegal subsidy to help offset some $\$ 1,200$ million in losses last year and perhaps make Bull a more attractive prospect for an outside buyer. Bull defended the aid as essentially no different than what a US electronics company would get from a Pentagon contract, or Japan from its industry ministries. Whatever the truth, Bull will have to do without, at least until Brittan's staff finishes their inquiry this fall.

Since the beginning of the year, Brittan has launched over 15 investigations into suspiciously generous state subsidies, including another FF 4,400 million (\$740 million) of ordinary capital that France wanted to invest in Bull and FF 1,800 million (\$305 million) earmarked to Thomson, the state-owned defence and electronics firm. Indeed, at least four of those 15 cases are in France, something that is at least partly due to the amount of money the country funnels into its industry: an average of 5,700 million ecu $(\$ 4,800$ million) a year, third most in Europe after Italy and Germany. But even more galling for Brittan is that France is the continent's least contrite offender.

French officials have accused Brittan of going beyond the intent of the EC rules, and undermining the very reason for state ownership. By demanding that governments act no differently than any other shareholder, they argue, Brittan is keeping France from one of the key advantages of socialism: the ability to make long-term investments in things like research, with- out demanding that a company show a profit every quarter.

"If we don't support Bull now, it will go bankrupt," says Patrick Baune, US representative of the French state-owned venture capital firm ANVAR. "But in two or three years in the future this kind of support will probably be forbidden."

Special exemptions to the EC rules allow for some government research funding to state-owned companies. But the amount of the support is inversely proportional to its proximity to market. So, for example, EC rules allow 50 per cent state support in basic or 'pre-competitive' research, but only 25 per cent when the research gets closer to development of an actual product.

One way around the muddle is to stick to EC-wide programmes and consortia for

\section{Washington}

A FORMER Massachusetts Institute of Technology (MIT) official has requested a scientific misconduct inquiry at the university's Plasma Fusion Center, claiming that researchers there manipulated data and that the MIT press office is conducting an "orchestrated attack" against cold fusion and its advocates.

Eugene Mallove, former chief science writer in the MIT news office and author of the recent pro-cold-fusion book Fire from Ice, claims in his complaint of 18 August that MIT researchers distorted a data curve so that they appeared to get the same results when their experimental apparatus was loaded with heavy water (containing deuterium) as they did when using ordinary water. He claims that this disguised real differences in heat output between the two experiments, and possible signs of cold fusion.

Robert Parker, head of the fusion centre and an author of the paper (Journal of Fusion Energy 9, 133-148; 1990) in which the curves are published, explains that the shifting of the heavy water data came as a result of a computer subtraction designed to compensate for water evaporation. In this case, deuterium cells were initially recorded as generating 20 milliwatts of excess power at certain points in the experiment. But because those measurements are well below the 40 milliwatt uncertainty assigned to the experimental apparatus, the MIT researchers argue that they were not significant.

Mallove also claims that Parker misled him into issuing a press release in May 1989 accusing the Boston Herald of misquoting Parker. In the article, Parker is quoted as describing the work of Stanley basic research. While Brittan casts a jaundiced eye on state research and development subsidies, Filippo Pandolfi, the EC's research commissioner, is doing everything he can to encourage collaborative state research support. European electronics companies control just 10 per cent of the world market and most - like Phillips of the Netherlands, Germany's SiemensNixdorf Information Systems, and Britain's International Computers Ltd. have posted losses in recent years. Pandolfi is encouraging the companies to form research partnerships and to participate in EC-supported programmes like ESPRIT (information technology), JESSI (semiconductors) and RACE (communications) to leverage their research money. As long as government support is through such international collaborations, Brittan can have little complaint - even if the money ultimately benefits individual companies.

Christopher Anderson

\title{
Cold fusion tempest at MIT
}

Pons and Martin Fleischmann, who claimed to have discovered cold fusion, as a fraud, a statement Parker denied in the press release. Mallove says that he later obtained a tape recording of the interview with the Herald which showed that Parker had in fact been quoted accurately in the article and had in fact used the word "fraud" several times. Parker says the usages were not in reference to the disputed work.

In his complaint, Mallove requests an investigation into the handling and representation of the fusion centre data, a decision on whether the Journal of Fusion Energy paper should be retracted or amended, and an examination of the behaviour of Parker and MIT researcher Ronald Ballinger "in orchestrating a public attack on the motives of researchers whose work they hoped to prove incorrect".

Robert DiIorio, a spokesman for MIT, declined to comment on the status of Mallove's request. But he says that "no complaint gets dismissed out of hand," and that the usual procedure in such a situation would be to set up a panel to review the allegations and decide whether to start a formal investigation.

In a statement released by MIT, Parker said that the Journal of Fusion Energy paper has been reviewed by MIT scientists and that, following the review, "the conclusions of the study stand as published."

Mallove resigned earlier this year from his news office post to protest (according to his resignation letter) the "unfortunate way the [cold fusion controversy] has been dealt with by MIT". He remains a lecturer in science journalism at the university.
Christopher Anderson 